\title{
Anthropometric features in predicting insulin resistance among non-menopausal Indonesian adult females
}

\author{
LIONG BOY KURNIAWAN ${ }^{1}$, BACHTIAR SYAMSIR ${ }^{1,2}$, ILHAM AKBAR RAHMAN ${ }^{3}$, ENDY ADNAN $^{4}$, \\ TENRI ESA ${ }^{1}$, YUYUN WIDANINGSIH ${ }^{1}$, ULENG BAHRUN ${ }^{1}$, MANSYUR ARIF $^{1}$ \\ ${ }^{1}$ Department of Clinical Pathology, Faculty of Medicine, Hasanuddin University, Makassar, Indonesia \\ ${ }^{2}$ Nabire Regional Hospital, Nabire, Papua, Indonesia \\ ${ }^{3}$ Bachelor of Medicine Programme Lecturer, Faculty of Medicine, Hasanuddin University, Makassar, Indonesia \\ ${ }^{4}$ Department of Internal Medicine, Faculty of Medicine, Hasanuddin University, Makassar, Indonesia
}

\begin{abstract}
Introduction. The prevalence of obesity is increasing worldwide in high, low, and middleincome countries such as Indonesia. Obesity rate is higher in females in Indonesia. Obesity has important contribution in the occurrence of insulin resistance (IR) and type 2 diabetes mellitus. Several anthropometric measurements such as waist circumference (WC), body mass index (BMI), body mass (BM), total body fat percentage (Fat $\%$ ) and visceral fat (VF) are related to IR. This study aimed to investigate which of those measurements could be used as a better predictor of IR in non-menopausal Indonesian adult females.

Methods. Total of 80 non-menopausal Indonesian adult females ranging from 21 to 40 years were recruited in this study. Insulin resistance was measured by using Homeostatic Model Assessment for Insulin Resistance (HOMA-IR) equation. Subjects with HOMA-IR index $\geq 75^{\text {th }}$ percentile with cut-off 2.74 were defined as IR. Waist circumference, BMI and BM were measured, while TF and VF were measured by bioelectrical impedance analysis (BIA).

Results. HOMA-IR had significant correlation with WC $(\mathrm{r}=0.563, \mathrm{p}<0.001)$, BMI $(\mathrm{r}=0.537$, $\mathrm{p}<0.001)$, BM $(\mathrm{r}=0.515, \mathrm{p}<0.001)$, VF $(\mathrm{r}=0.515, \mathrm{p}<0.001)$, Fat $\%(\mathrm{r}=0.490, \mathrm{p}<0.001)$. The area under curve of VF (0.809), BMI (0.807), WC (0.805), and BM (0.799) are slightly larger than and Fat\% (0.766).

Conclusion. Insulin resistance had strong correlation with all anthropometric measurements, but the correlation was less significant with Fat $\%$.
\end{abstract}

Key words: insulin resistance, anthropometric, female, non-menopausal.

\section{INTRODUCTION}

Obesity can be defined simply as excess of human body weight for height and further associated with excess of body fat percentage and distribution [1]. It is estimated that about 2 billion people are suffering from overweight and about one third of the overweight subjects are obese in the world nowadays [2]. The prevalence of obesity and central obesity in Indonesian adult people are reported to be $23.1 \%$ and $28 \%$ respectively. The prevalence of both conditions is higher in females than in males [3]. The condition of overweight and obesity is not only a matter of appearance but also a matter of health in the perspective of young adult women [4]. Obesity has strong relationship with the development of insulin resistance, metabolic syndrome, diabetes mellitus (DM), cardiovascular complications [5].

Insulin resistance (IR) is defined as insulin action defect which results in the production of more insulin in order to keep the blood glucose levels within normal range. The gold standard in assessing the insulin resistance is by using euglycemic hyperinsulinemic clamp technique. This technique has some difficulties to perform, so that other more simple IR measurements are developed, such as homeostasis model assessment of IR (HOMA-IR), which is commonly used as an alternative method for evaluating IR [6]. This model was developed by Matthew et al. and had strong correlation with the results of the clamp gold standard technique in evaluating IR and more convenient to perform [7].

Several anthropometric measurements such as body mass (BM), body mass index (BMI), waist circumference (WC) are commonly used to evaluate obesity. Total body fat percentage (Fat $\%)$ and visceral fat (VF) level measured by bioelectrical impedance technique are some of recently parameters used to measure obesity. The parameters above are shown to have strong correlation with IR in middle age and elderly people $[8,9]$. The study about the 
relationship of anthropometric parameters with IR which focused on the non-menopausal female adult is still rare. This study aimed to evaluate the association of BM, BMI, WC, Fat\%, VF with IR and stratifying their diagnostic value in prediting IR among non-menopausal Indonesia.

\section{MATERIALS AND METHODS}

\section{Study design and participants}

This research was an analytical study with cross-sectional design performed from October 2018 to March 2019. All voluntary subjects were nondiabetic non-menopausal adult females with age ranged from 18 to 40 years old, who were willing to take part in the study and gave written informed consent. This research only focused on female adults because male adults had different body fat distribution compared to female and had to be observed separately in the other study for its bias potential. This study was only limited to nonmenopausal subjects because low estrogen level in menopausal might alter the insulin resistance. Total of 80 participants were recruited to join this research. All subjects had an overnight fasting for at least 8 hours and fasting blood samples were collected. Anthropometric data of all participants were also measured. All research subjects were Asian with mostly Indonesian mongoloid race. We excluded subjects who used medications including corticosteroids, suffered diabetes mellitus or taking anti diabetic agents, used hormonal contraception medication. This research was part of study approved by Komite Etik Penelitian Kesehatan (Health Research Ethical Committee), Faculty of Medicine, Hasanuddin University, Makassar, Indonesia with Recommedation Number 729/H4.8.4.5.31/PP36-KOMETIK/2018, and complied with the Helsinki Declaration.

\section{Anthropometric measurements and laboratory tests}

Anthropometric data were measured by a single examiner. Height and $\mathrm{BM}$ of the subjects were measured, then BMI was calculated with equation of weight $(\mathrm{kg})$ divided by height squared $\left(\mathrm{m}^{2}\right)$. WC was measured by measuring tape at midway level between lower border of $12^{\text {th }}$ rib and iliac crist. The Fat $\%$ and VF were calculated by using Tanita-BC541 (Tokyo, Japan) bioelectrical impedance analysis (BIA) device. Blood samples were collected after at least 8 hour overnight fasting periode. Glucose levels were measured using Abx Pentra 400 (Horiba, USA) while the insulin levels were measured by using Elecsys 2010 (Roche, Indianapolis, IN, USA).

Insulin resistance was measured by using calculated model of the homeostatis model asessment of insulin resistance (HOMA-IR) index $=($ Insulin $[\mu \mathrm{IU} / \mathrm{mL}] \times$ Fasting Plasma Glucose $[\mathrm{mg} / \mathrm{dL}] / 405$ [7]. HOMA-IR value above 75 percentile was used as cut-off in defining the insulin resistance state in non-menopausal female adult. In this study, the cut-off value used for defining IR was 2.74. All of HOMA-IR values below the cuf-off point were defined as non-IR/ insulin sensitive.

\section{Statistical analysis}

The data distribution normality was measured using Kolmogorov-Smirnov test. All data which were distributed normally expressed as mean \pm standard deviation (SD) while those which were not distributed normally expressed as median (minimum-maximum). Only Fat $\%$ percentage was distributed normally while other parameters including age, BM, BMI, $\mathrm{WC}, \mathrm{VF}$, fasting plasma glucose (FPG), insulin, and HOMA-IR were not distributed normally. The correlation between HOMA-IR and all other parameters were analyzed using Spearman Test for non-parametric correlation. The receiver operating characteristic (ROC) curves were used to evaluate the significance of $\mathrm{BM}, \mathrm{BMI}, \mathrm{WC}, \mathrm{Fat} \%$ and $\mathrm{VF}$ as IR predictors. The area under the ROC curve (AUC) and the optimal cut-off point in predicting IR of BM, BMI, WC, Fat $\%$ and VF were determined by the largest sum of sensitivity and specificity. All statistical tests were performed using the Statistical Package for the Social Sciences, Version 21.0 (SPSS Inc, Chicago, IL, USA). Statistical analysis was considered significant if $\mathrm{p}<0.05$.

\section{RESULTS}

The characteristic of all subjects, IR and non-IR subjects are shown in Table 1 . There is no significant difference of age between IR and nonIR Groups. Obese parameters including BM, BMI, $\mathrm{WC}, \mathrm{Fat} \%$, and VF are significantly higher in IR group compared to those in non-IR group. FPG, insulin levels, and HOMA-IR index are significantly higher in IR group.

All obesity indices including BM, BMI, $\mathrm{WC}$, Fat $\%$, and VF show significant correlation with IR (HOMA-IR) (Table 2). 
Table 1

Characteristics of all, IR and non-IR subjects

\begin{tabular}{|l|c|c|c|c|}
\hline \multicolumn{1}{|c|}{ Variable } & All $(\mathbf{n}=\mathbf{8 0})$ & Non-IR (n= 60) & IR (n= 20) & p \\
\hline Age, $\mathrm{yr}$ & $32(21-40)$ & $32(21-40)$ & $32(27-39)$ & $0.385^{*}$ \\
\hline BM, $\mathrm{kg}$ & $57.60(40-92.50)$ & $55.80(40-75.80)$ & $67.75(51.60-92.50)$ & $<0.001^{*}$ \\
\hline BMI, $\mathrm{kg} / \mathrm{m}^{2}$ & $23.50(17.80-38.50)$ & $23.15(17.80-32.70)$ & $28.35(21.30-38.50)$ & $<0.001^{*}$ \\
\hline WC, $\mathrm{cm}$ & $80(65-105)$ & $79(65-101)$ & $90(72-105)$ & $<0.001^{*}$ \\
\hline Fat $\%$ & $32.96+4.53$ & $31.89 \pm+3.89$ & $36.18 \pm+4.87$ & $0.001^{\#}$ \\
\hline VF & $6(2-27)$ & $5(2-17)$ & $10.5(3-27)$ & $<0.001^{*}$ \\
\hline FPG, $\mathrm{mg} / \mathrm{dL}$ & $88.70(63.90-125)$ & $86.60(63.90-105)$ & $93.90(76.70-125)$ & $<0.001^{*}$ \\
\hline Insulin, $\mu \mathrm{IU} / \mathrm{mL}$ & $9.1(2.74-42.46)$ & $7.67(2.74-12.07)$ & $13.92(11.96-42.46)$ & $<0.001^{*}$ \\
\hline HOMA-IR & $1.95(0.60-12.61)$ & $1.60(0.60-2.70)$ & $3.41(2.75-12.61)$ & $<0.001^{*}$ \\
\hline
\end{tabular}

Data are expressed as mean \pm standard deviation for normally distributed variables and median (minimum-maximum) for non-normally distributed variables. Subjects are divided into 2 groups, Non-IR and IR based on HOMA-IR $>75$ percentile value (cut-off 2.74 ). $P$ value is used to measure the difference between non-IR and IR groups. IR $=$ insulin resistance, $\mathrm{BM}=$ body mass, $\mathrm{BMI}=$ body mass index, $\mathrm{WC}=$ waist circumference, $\mathrm{Fat} \%=$ total body fat percentage, $\mathrm{VF}=$ visceral fat, $\mathrm{FPG}=$ fasting plasma glucose, HOMA-IR $=$ homeostatic model assessment for insulin resistance

*Mann Whitney Test; ${ }^{\#}$ T Test

Table 2

Correlation of IR (HOMA-IR) with obesity indices

\begin{tabular}{|l|c|c|}
\hline \multicolumn{1}{|c|}{ Variable } & Correlation coefficient $^{*}$ & $\mathbf{p}^{\prime}$ \\
\hline BM & 0.515 & $<0.001$ \\
\hline BMI & 0.537 & $<0.001$ \\
\hline WC & 0.563 & $<0.001$ \\
\hline FAT\% & 0.490 & $<0.001$ \\
\hline VF & 0.515 & $<0.001$ \\
\hline
\end{tabular}

$\mathrm{IR}=$ insulin resistance, $\mathrm{BM}=$ body mass, $\mathrm{BMI}=$ body mass index, $\mathrm{WC}=$ waist circumference, $\mathrm{Fat} \%=$ total body fat percentage, $\mathrm{VF}=$ visceral fat

${ }^{*}$ Spearman Correlation Test

ROC curve shows (figure not shown) the AUC of all obesity indices including BM, BMI, WC, Fat $\%$, and VF have strong prediction value of IR. VF has slightly a better prediction value than other indices. VF and BMI have the highest sensitivity by using cut-off 6.5 and 24.95 respectively whereas
$\mathrm{BM}$ and Fat $\%$ have the highest specificity by using cut-off 62 and 34.35 respectively (Table 3 ).

Logistic regression shows every 1 point of the increase of BM, BMI, WC, Fat $\%$, and VF increases $1.144,1.456,1.164,1.291,1.400$ occurance rate of IR respectively (Table 4).

Table 3

The AUC, sensitivity, and specificity of obesity indices by the most optimal cut-off point in predicting IR

\begin{tabular}{|l|c|c|c|c|}
\hline \multicolumn{1}{|c|}{ Variables } & AUC (95\% CI) & Sensitivity & Specificity & Cut-off Point \\
\hline BM & $0.799(0.690-0.908)$ & 0.750 & 0.767 & 62 \\
\hline BMI & $0.807(0.685-0.928)$ & 0.800 & 0.750 & 24.95 \\
\hline WC & $0.805(0.687-0.923)$ & 0.750 & 0.723 & 83.5 \\
\hline Fat\% & $0.766(0.623-0.909)$ & 0.750 & 0.767 & 34.35 \\
\hline VF & $0.809(0.686-0.933)$ & 0.800 & 0.733 & 6.5 \\
\hline
\end{tabular}

$\mathrm{AUC}=$ area under the ROC curve, $\mathrm{IR}=$ insulin resistance, $\mathrm{BM}=$ body mass, $\mathrm{BMI}=$ body mass index, $\mathrm{WC}=$ waist circumference, Fat $\%=$ total body fat percentage, $\mathrm{VF}=$ visceral fat

\section{Table 4}

Logistic regression analysis of obesity indices for determining IR

\begin{tabular}{|l|c|c|c|c|}
\hline \multirow{2}{*}{ Variables } & \multirow{2}{*}{$\mathbf{p}$} & \multirow{2}{*}{ OR } & Lower & 95\% CI \\
\cline { 3 - 5 } & & 1.144 & 1.064 & 1.230 \\
\hline BM & $<0.001$ & 1.456 & 1.206 & 1.757 \\
\hline BMI & $<0.001$ & 1.164 & 1.075 & 1.260 \\
\hline WC & $<0.001$ & 1.291 & 1.113 & 1.496 \\
\hline Fat $\%$ & 0.001 & 1.400 & 1.176 & 1.666 \\
\hline VF & $<0.001$ &
\end{tabular}

$\mathrm{IR}=$ insulin resistance, $\mathrm{BM}=$ body mass, $\mathrm{BMI}=$ body mass index, $\mathrm{WC}=$ waist circumference, $\mathrm{Fat} \%=$ total body fat percentage, $\mathrm{VF}=$ visceral fat 


\section{DISCUSSION}

In this research, we found the cut-off value of HOMA-IR in defining IR among non-menopausal Indonesian female adults (age 21 to 40 years old) was 2.74 . This cut-off was slightly higher than the cut-off $2.3\left(\geq 75^{\text {th }}\right.$ percentile $)$ reported by Cheng et al. who performed research among middle-aged and elderly Taiwanese with the mean subjects age of $64.41+8.46$ years [9]. This difference might be due to the difference of population age and ethnicity. Different cut-off value was also reported from Spanish population. The threshold value of HOMA-IR was 2.05 which used the account of metabolic syndrome components in defining IR [10]. This difference might due to the different ways used to define IR because there still no universal agreement in defining IR and difference of ethnicity. Our previous study also reported different cut-off (3.75) in defining IR in healthy young male adults [11]. The male had higher cut-off than in female population. The cutoff was even higher while defining type 2 diabetes mellitus (T2DM). In Czech population, the cut-off of HOMA-IR used for diagnosing T2DM was 3.63 [12]. In Korean population, HOMA-IR cut-off value for identifying dysglycemia was 1.6 in male and female, and increased to 2.87 in men and 2.36 in women when used to diagnose T2DM [13].

Our findings showed that all obesity indices analyzed in this study including BM, BMI, WC, Fat $\%$, and VF, all had significant correlation with HOMAIR. AUC analysis showed that VF had the largest area than other obecity indices (BMI, WC, BM, and Fat $\%)$ with the best cut-off 6.5 (0.8 sensitivity and 0.733 specivicity) in non-menopausal population. We proposed this cut-off as simple IR predictor in non-menopausal Indonesian female adult population. Another interesting results were also found in this study. The BMI cut-off value of $24.95 \mathrm{~kg} / \mathrm{m}^{2}$ in defining IR was so closely met to World Health Organization obesity criteria for Asian population (using $25 \mathrm{~kg} / \mathrm{m}^{2}$ ) in defining obesity. It means that the obese non-menopausal female adults (based on $\mathrm{BMI})$ in our population can also be predicted to suffer from IR. The WC cut-off value of $83.5 \mathrm{~cm}$ in defining IR was also near to the criteria of Asian adult women $(\mathrm{WC}>80 \mathrm{~cm}$ ) in defining abdominal obesity. It means that centrally obese women have a greater chance to have IR.
Our study method which used cross-sectional method could not explain the causality and pathophysiology why VF had the best predictor value compared to other obesity indices. Further studies are needed to explain it. BMI and WC are traditional obesity indices used worldwide, while VF and Fat $\%$ measured by BIA method are used frequently these recent years as newer obesity indices. There was a good agreement between fat measured by BIA method and by referenced magnetic resonance imaging (MRI) [14]. The correlation between body fat mass measured by BIA method and the volume of adipose tissue measured by MRI was 0.81 for male and 0.75 for female hence BIA could be used as alternative method in measuring body fat [15]. In this study, VF, BMI, WC, and BM had slighly larger AUC than and Fat\% showing in diagnosing IR. Some explainations might describe that. Visceral fat has greater lipolytic potential compared to other fat including subcutaneous fat. The lipolytic feature then will increase the production of free fatty acid. The free fatty acid deliverence to hepar will induce the occurance of hepatic insulin resistance. WC can also be used to reflect the visceral fat amount [16]. One possible reason why Fat $\%$ had slighly weaker predicting value compared to other parameters might be explained by the fact that it did not only measure white adipose tissue which was composed by mostly visceral adipose tissue, but also measured brown adipose which was likely not related to IR [17].

This was one of the few studies reporting the cut-off value of HOMA-IR in defining IR focusing in non-menopausal female adults in South East Asia region especially in Indonesian population.

There are several limitations of our study. First, HOMA-IR is only reflecting hepatic IR in basal condition and does not fully describe other peripheral organs (fat and muscle) IR as the euglycemic reference method does. Second, the cross-sectional design could not explain the causality relationship among obesity indices with IR. Third, this study was from a single center and did not represent all Indonesian multi ethnics population. Further larger multi center studies with multi ethnics population should be performed to generalize this cut-off value.

In conclusion, we summarized that all obesity indices including BM, BMI, WC, Fat $\%$, and VF had significant correlation with HOMA-IR and could be used to define IR. Among all, VF, BMI, WC, and BM had slightly better IR predictor value compared to Fat $\%$ in non-menopausal female adults population.

Introducere. Prevalenţa obezităţii este în creștere inclusiv în Indonezia. Obezitatea are o importanţă deosebită pentru dezvoltarea rezistenţei la insulină (IR) şi a diabetului zaharat de tip 2. IR este asociată cu modificarea anumitor indici antopometrici: 
indicele de masă corporală (BMI), circumferinţa abdominală (WC), procentul de grăsime (Fat\%) și grăsimea viscerală (VF). Studiul investighează care dintre aceşti indici se asociază cu IR în populaţia feminină indoneziană adultă aflată la premenopauză.

Materiale şi metode. Pentru acest studiu au fost recrutate 80 de femei premenopauză din Indonezia cu vârste între 21 şi 40 ani. IR a fost măsurată prin HOMA-IR. Pacienţii peste percentila $75 \mathrm{cu}$ valoarea prag de 2,74 au fost consideraţi cu IR. Au fost măsurate BMI, WC, \%Fat, VF.

Rezultate. HOMA-IR s-a corelat cu WC $(r=0,563, p<0,001), B M I(r=0,537$, $p<0,001), B M(r=0,515, p<0,001), V F(r=0,515, p<0,001)$, Fat $\%(r=0,490$, $p<0,001)$. Aria de sub curbă pentru VF $(0,809), B M I(0,807)$, WC $(0,805)$ şi BM $(0,799)$ au fost uşor mai mari decât cea pentru \%Fat $(0,766)$.

Concluzii. IR s-a corelat cu toți indicii antropometrici însă mai puțin cu \%Fat.

Correspondence to: Liong Boy Kurniawan, Medical Faculty, Hasanuddin University, Perintis Kemerdekaan KM 10 Road, Makassar 90245, South Sulawesi, Indonesia

Mobile number: +6281241738007

Email: liongboykurniawan@yahoo.com

Conflict of interest disclosure: The authors have no conflicts of interest associated with the material presented in this paper.

\section{REFERENCES}

1. HRUBY A., HU FB. The epidemiology of obesity: a big picture. Pharmacoeconomics. 2015; 33(7):673-689.

2. SEIDELL JC., HALBERSTADT J. The global burden of obesity and the challenges of prevention. Ann Nutr Metab. 2015; 66(suppl 2):7-12.

3. HARBUWONO DS., PRAMONO LA., YUNIR E., SUBEKTI I. Obesity and central obesity in Indonesia: evidence from a national health survey. Med J Indones. 2018; 27(2):114-120.

4. SAND AS., EMAUS N., LIAN O. Overweight and obesity in young adult women: a matter of health or appearance? The Thomso study: fit futures. International Journal of Qualitative Studies on Health and Well-being. 2015; 10: 29026.

5. BALSAN GA., VIEIRA JLDC., OLIVEIRA AMD., PORTAL VL. Relationship between adiponectin, obesity and insulin resistance. Rev Assoc Bras. 2015; 61(1):72-80.

6. RODRIGUES TC., CANANI LH., GROSS JL. Metabolic syndrome, insulin resistance and cardiovascular disease in type-1 diabetes mellitus. Arq Bras Cardiol. 2010; 94(1):125-130.

7. MATTHEWS DR., HOSKER JP., RUDENSKI AS., NAYLOR BA., TREACHER DF., TURNER RC. Homeostatis model assessment: insulin resistance and beta-cell function from fasting plasma glucose and insulin consentration in man. Diabetologia. $1985 ; \mathbf{2 8}: 412-419$.

8. ANUNCIACAO PC., RIBEIRO RDCL. Anthropometric indicators in identification of insulin resistance in elderly men. O Mundo da Saude, Sao Paulo. 2015; 39(2):157-163.

9. CHENG YH., TSAO YC., TZENG IS., CHUANG HH., LI WC., TUNG TH., et al. Body mass index and waist circumference are better predictors of insulin resistance than total body fat percentge in middle-aged and elderly Taiwanese. Medicine. $2017 ; 96: 39$.

10. DIZ PG., GONZALES AO., ALVAREZ MXR., GUDE F., GARCIA F., FRANCISCO AD., et al. Insulin resistance (HOMA-IR) cut-off values and the metabolic syndrome in a general adult population: effect of gender and age: EPIRCE cross-sectional study. BMC Endocrine Disorders. 2013; 13:47.

11. KURNIAWAN LB., BAHRUN U., HATTA M., ARIF M. Body mass, total body fat percentage, and visceral fat level predict insulin resistance better than waist circumference and body mass index in healthy young male adults in Indonesia. Journal of Clinical Medicine. 2018; 7:96.

12. HORAKOVA D., STEPANEK L., JANOUT V., JANOUTOVA J., PASTUCHA D., KOLLAROVA H., et al. Optimal homeostasis model assessment of insulin resistance (HOMA-IR) cut-offs: a cross-sectional study in the Czech population. Medicina. 2019; 55:158.

13. BAEK JH., KIM H., KIM KY., JUNG J. Insulin resistance and the risk of diabetes and dysgycemia in Korean general adult population. Diabetes \& Metabolism Journal. 2018; 42:296-307.

14. BORGA M., WEST J., BELL JD., HARVEY NC., ROMU T., HEYMSFIELD SB., et al. Advanced body composition assessment: from body mass index to body composition profiling. J Investig Med. 2018; 66:887-895.

15. ULBRICH EJ., NANZ D., LEINHARD OD., MARCON M., FISCHER MA. Whole-body adipose tissue and lean muscle volumes and their distribution across gender and age: MR-derived normative values in a normal-weight Swiss population. Magnetic Resonance in Medicine. 2018; 79(1):449-458.

16. HAYASHI T., BOYKO EJ., MCNEELY MJ., LEONETTI DL., KAHN SE., FUJIMOTO WY. Visceral adiposity, not abdominal subcutaneous fat area, is associated with an increase in future insulin resistance in Japanese Americans. Diabetes. 2008; 57:1269-1275.

17. CASTRO AV., KOLKA CM., KIM SP., BERGMAN RN. Obesity, Insulin Resistance and Comorbidities - Mechanisms of Association. Arq Bras Endocrinol Metabol. 2014; 58(6):600-609.

Received April $10^{\text {th }} 2020$ 